\section{Is there a God?}

SiR-Bruce Denness (Nature 336, 614; 1988) suggests that God was smart enough to cover his tracks in his recent creation of the Universe by fabricating evidence of an ancient origin. That God should engage in such a fraudulent practice, which could be designed to mislead the most intelligent of his creatures, must undermine any trust we have in him. If God tells us lies, of what value is his Word?

If God is honest, the Universe is as old as the evidence suggests. If God doesn't exist at all, the Universe is as old as the evidence suggests.

4 York Avenue,

Willenhall,

West Midlands, WV13 1JJ, UK

SIR-The argument put forward by Bruce Denness was proposed and developed at great length by the British naturalist Philip H. Gosse (1810-88) in his book Omphalos (c.1857).

Bertrand Russell in Religion and Science (London, 1958) made the following comments on this theory.

"There is no logical possibility of proving that this theory is untrue . . but if once such possibilities are admitted, there is no reason to place the creation of the world at one point rather than another. We may have all come into existence five minutes ago, provided with ready-made memories, with holes in our socks and hair that needed cutting. But although this is a logical possibility, nobody can believe it; and Gosse found, to his bitter disappointment, that nobody could believe his logically admirable reconciliation of theology with the data of science".

Ch. Des Etroubles 19,

IOHN BLEEKER

1213 Onex, Switzerland

SIR-Bruce Denness has recently confessed that he "cannot find a way around" the argument that, "if God was smart enough to create The System, he was certainly smart enough to cover his tracks, that is he could have 'implanted' the geological [and] astronomical record so that what many of us now see as a scientifically pre-Creation history is merely a divine artefact." Let me reassure him, and any others similarly distressed, that they are neither the first, nor the most luminous, scientists to be flummoxed by this devious conjecture.

Such arguments are dismissed, not by supplying contradictory evidence, but by observing that there can be none. Such diabolical speculations simply define conflicting data out of existence. Science gives them short shrift, not because they are demonstrably wrong, but because they are scientifically vacuous: (1) they are unfalsifiable, because they fail to state how the world we observe would be different if it were not a divine artefact; (2) they have no explanatory power, as they cower from the question of why this particular divine artefact, out of the infinite alternatives; (3) they are predictively useless, as the putative divinity of the Universe's origin does nothing to restrict its sphere of future possibilities; and (4) they are radically unparsimonious, because they impose an extraordinary burden of unverifiable assumption, while conferring no predictive utility in return. Science refuses to believe in miracles, because believing in miracles is scientifically useless, not because they can be scientifically refuted.

The fact that science has chosen falsifiability, parsimony and predictive and explanatory utility as its precepts, and therefore cannot offer proof or data for them, does not mean that, in Denness's words, "science would also appear to be a religion". Rather, it is precisely the adoption of these precepts (instead of others) that fundamentally distinguishes the scientific enterprise from the religious experience, and from most other aspects of daily life.

Energy and Resources Group,

JAMES KIRCHNER

University of California,

Berkeley, California 94720, USA

SIR-Bruce Denness's conclusion that God was smart enough both to create The System and to cover his tracks thereafter (Nature 336, 614; 1988) has scriptural backing. Isaiah 45.15 affirms: "Verily thou art a God that hidest thyself, O God of Israel, the Saviour." (King James version.)

In Job 38.4, God asks Job: "Where were you when I laid the foundations of the earth? Tell me if you know so much." (The Living Bible version.)

As for his second point that science would also appear to be a religion, at least one notable scientist in the person of Freeman Dyson supports him by arguing that science and religion are similar (D.G. King-Hele Nature 332, 748; 1988).

Reginald T. Chelvam

1740 West 27th Street, Suite 301 ,

Houston,

Texas 77008, USA

SIR-Bruce Denness asks for a way around the argument about a creator-god who was "smart enough to cover his tracks" by implanting geological and astronomical evidence for pre-creation history.

Besides the question of what might be the motivation of this puckish god, the trouble with Denness's idea is the same as that with the slightly more extreme idea tht the world began literally one minute ago - including, of course, all the books in the libraries and all the memories in our minds. The trouble is twofold: (1) By the very construction of such hypotheses, it is impossible either to refute or to confirm them, and (2) even worse is the fact that they are sterile: absolutely nothing logical or practical follows from them. So although such ideas make some people emotionally comfortable, they are simple dead ends, and not any kind of science.

To be sure, various religions add on to the supernatural-creation hypothesis several more hypotheses, such as the Garden of Eden, Noachian flood, Ten Commandments, Virgin Birth and Resurrection. But these are just additional hypotheses, not logically connected with one another, and the truth or falsity of one of them says nothing about the truth or falsity of any other. For example, if someone should ever find a piece of very old wood on Mount Ararat, this could be construed as evidence for a great flood, but it would mean nothing at all to the hypothesis of supernatural creation.

It needs to be pointed out over and over again that supernatural creation is not a theory, but just a hypothesis (and a sterile one at that), while biological, geological and astronomical evolution are full-blown scientific theories, consistent with each other and with a lot of data.

Edgar Pearlstein

Behlen Laboratory of Physics,

University of Nebraska,

Lincoln,

Nebraska, 68588-0111, USA

SIR-The answer to Bruce Denness was surely given many years ago by Albert Einstein: "Raffiniert ist der Herr Gott, aber boshaft ist Er nicht." ("God is cunning but he's not malevolent.")

Nicholas Ryan Consultancy Ltd,

Nicholas Ryan 14 Charlotte Mews,

London W1P1LN,

$U K$

\section{Capital idea}

SIR-In your leading article "Student debtors rally" (Nature 336, 411; 1988), you say "Capital cities are incomplete without occasional conflicts between students and the authorities ....".

This is the very reason why the wise authorities of the past would never have thought of having a university in their capital city. Thus Padua not Venice, Pavia not Milan, Uppsala not Stockholm and, of course, Oxford and Cambridge not London.

The fact that Venice, Milan, Stockholm and London now all have universities of a sort does not mean that some authority might not seriously consider reverting to the old wise practice.

Marco Fraccaro

Collegio Cairoli,

Piazza Collegio Cairoli 1,

27100 Pavia,

Italy 